e-Jurnal Ilmiah BIOSAINTROPIS (BIOSCIENCE-TROPIC)

Volume 7/ No.: 2 / Halaman 126 - 132 / Januari Tahun 2022

ISSN : 2460-9455 (e) - 2338-2805(p)

\title{
Efektivitas Antiseptik Ekstrak Jeruk Nipis dan Lidah Buaya Terhadap Jamur Candida Albicans
}

\author{
Lukky Jayadi $^{1 *}$, Sandry Kesuma ${ }^{2}$ \\ 1,2 Analis Farmasi dan Makanan, Politeknik Kesehatan Kementerian Kesehatan Malang, Indonesia \\ ${ }^{*}$ Koresponden Penulis : lukky.jayadi@gmail.com
}

\begin{abstract}
ABSTRAK
Pemanfaatan antiseptik sebagai penataan di lingkungan sekitar telah menjadi gaya hidup. Beberapa pengaturan pembersihan tangan dapat ditemukan di tempat pengamatan. Alkohol umumnya digunakan sebagai bahan bebas kuman untuk membersihkan permukaan dan membersihkan kulit, tetapi tidak selalu untuk luka. Alkohol sebagai desinfektan memiliki fungsi bakterisida, menetralkan berbagai jenis organisme mikroorganisme, jamur dan virus. Penelitian ini bertujuan untuk membuat pembersih antiseptik dengan ekstrak jeruk nipis dan lidah buaya yang dapat membunuh jamur Candida albicans. Dalam tinjauan ini, pH pengukuran ditunjukkan dengan nilai 5 dan untuk pengujian bobot jenis didapatkan hasil adalah $0,9736 \mathrm{~g} / \mathrm{ml}$. Pengujian percentage kill sediaan antiseptik dengan dua waktu kontak uji yaitu 30 dan 60 detik. Hasil percentage kill sediaan antiseptik dengan dua kali waktu kontak uji ini didapatkan percentage kill senilai 99,9\%. Ada pengaruh penggunaan antiseptik dengan kandungan alkohol dengan penambahan ekstrak jeruk nipis dan lidah buaya terhadap $\mathrm{pH}$, bobot jenis dan daya bunuh jamur.
\end{abstract}

Kata kunci: Antiseptik, Buah Jeruk Nipis, Candida albicans, Lidah Buaya

\begin{abstract}
The use of antiseptics as an arrangement in the surrounding environment has become a lifestyle. Several hand sanitizing arrangements can be found at the lookout. Alcohol is generally used as a germ-free agent to clean surfaces and clean the skin, but not always for wounds. Alcohol as a disinfectant has a bactericidal function, neutralizing various types of microorganisms, fungi and viruses. This study aims to make an antiseptic cleanser with lime and aloe vera extracts that can kill the fungus Candida albicans. In this review, the $\mathrm{pH}$ measurement is indicated by the value 5 and for the specific gravity test the result is $0.9736 \mathrm{~g} / \mathrm{ml}$. Testing the percentage kill of antiseptic preparations with two test contact times, namely 30 and 60 seconds. The results of the percentage kill of antiseptic preparations with twice the contact time of this test obtained a kill percentage of $99.9 \%$. There is an effect of using antiseptic with alcohol content with the addition of lime extract and aloe vera on $\mathrm{pH}$, specific gravity and killing power of fungi.
\end{abstract}

Keywords: Aloe Vera, Antiseptic, Candida albicans, Lime

doi: $10.33474 /$ e-jbst.v7i2.483

Diterima tanggal 3 Desember 2021- Diterbitkan Tanggal 28 Januari 2022 http://creativecommons.org/licenses/by/4.0 
e-Jurnal Ilmiah BIOSAINTROPIS (BIOSCIENCE-TROPIC)

Volume 7/ No.: 2 / Halaman 126 - 132 / Januari Tahun 2022

ISSN : 2460-9455 (e) - 2338-2805(p)

\section{Pendahuluan}

Beberapa penyakit yang sering menginfeksi yaitu jamur, contohnya Candida albicans yang merupakan mikroorganisme umum dalam tubuh manusia. Kontaminasi Candida albicans dapat bersifat esensial atau tambahan, bergantung pada ketahanan tubuh manusia yang terinfeksi. Kontaminasi Candida albicans pada manusia umumnya disebut kandidiasis. Kandidiasis terjadi di seluruh dunia dan mempengaruhi manusia, semuanya jenis kelamin, semua orang. Candida spp dapat bertumbuh, yang biasanya hidup di bagian tubuh manusia termasuk mukosa genital, sistem pencernaan dan saluran pernapasan bagian atas. Bagaimanapun, jika populasi Candida $s p$ berkembang, itu dapat menyebabkan masalah atau penyakit. Candida albicans adalah organisme yang menyerang orang-orang dengan pertahanan imun lemah dan merupakan pertumbuhan yang menyebabkan sariawan, kondisi jaringan tidak normal pada kulit, vulvavaginitis, kandiduria, kandidiasis gastrointestinal yang dapat menyebabkan sakit maag atau bahkan menyebabkan penyakit kronis [1].

Berlimpahnya pertumbuhan Candida albicans dapat menyebabkan kontaminasi pada vagina yang disebut Candidiasis vaginitis. Pencemaran ini sering terjadi karena pemanfaatan air, misalnya toilet yang mengandung Candida sp. Setelah buang air besar, kotoran dari kuku atau air digunakan untuk membersihkan diri. Candida albicans sering menyebabkan vaginitis pada wanita dengan gejala utama keluarnya cairan selain darah dari liang vagina yang sering disertai dengan kesemutan, Candida albicans dianggap sebagai spesies yang paling patogen dan merupakan penyebab kandidiasis yang paling dikenal. Kandidiasis adalah penyakit menular yang menyerang kulit, rambut, kuku, selaput lendir dan organ dalam yang disebabkan oleh berbagai genus Candida. Spesies yang paling banyak ditemukan pada manusia adalah Candida albicans. Kandidiasis adalah penyakit intens atau subakut yang disebabkan oleh Candida albicans atau kadang-kadang oleh Spesies berbeda yang dapat menyerang jaringan tubuh yang berbeda [2].

Antiseptik adalah suatu bahan yang menghambat atau membunuh mikroorganisme dengan mencegah pertumbuhan atau menghambat aktivitas metabolismenya. Antiseptik alami atau dari bahan herbal yaitu seperti jeruk nipis sedangkan antiseptik non herbal umumnya mengandung senyawa kimia. Penggunaan antiseptik di dalam upaya untuk melenyapkan bakteri dan jamur merupakan langkah yang penting untuk pencegahan terjadinya infeksi. Penyakit infeksi adalah penyakit yang terjadi akibat mikroorganisme patogen seperti virus, bakteri, parasit, dan jamur [3].

Reaksi positif terhadap penggunaan antiseptic untuk tangan mungkin terkait dengan kebersihan adalah suatu hal yang baik, serta penggunaannya yang layak. Bahan antiseptik yang digunakan dalam beberapa formulasi antiseptik adalah dari kelompok alkohol (etanol, propanol, isopropanol) dengan jarak konsentrasi $50-70 \%$ dan berbagai jenis pembersih seperti klorheksidin, triclosan. Bagaimanapun, karena merupakan pelarut alami, alkohol dapat memecah lapisan lemak dan sebum pada kulit, di mana lapisan tersebut berfungsi sebagai pelindung terhadap penyakit yang disebabkan mikroorganisme. Selain itu, alkohol mudah terbakar dan penggunaan berulang menyebabkan kekeringan dan gangguan pada kulit. Kelompok fenol yang digunakan pada formulasi sediaan antiseptik adalah triclosan. Kelebihan triclosan dibandingkan fenol adalah tidak terlalu berbahaya [4].

Lidah buaya mengandung polifenol, saponin, tanin, dan flavonoid yang memiliki fungsi sebagai bahan sterilisasi seperti antiseptik [5]. Gel lidah buaya mengandung 17 asam amino yang penting bagi tubuh. Kandungan dalam lidah buaya membuat tanaman ini menjadi tanaman serbaguna. Zat seperti saponin, aloin, emodin, pitch, lignin, antrakuinon, nutrisi, mineral. Lidah buaya dapat dimanfaatkan dalam industri dengan diolah menjadi gel, bubuk, ekstrak [6]. Saponin memiliki kemampuan sebagai bahan pembersih yang berkhasiat untuk menyembuhkan luka, sedangkan tanin dapat digunakan untuk mencegah penyakit luka karena memiliki fungsi sebagai antiseptic dan bersifat menyembuhkan. Flavonoid dan polifenol memiliki tindakan sebagai desinfektan. Lidah buaya sebagai 
e-Jurnal Ilmiah BIOSAINTROPIS (BIOSCIENCE-TROPIC)

Volume 7/ No.: 2 / Halaman 126 - 132 / Januari Tahun 2022

ISSN : 2460-9455 (e) - 2338-2805(p)

antiseptik tangan yang steril terhadap jumlah bakteri. Ditemukan bahwa lidah buaya dapat menurunkan jumlah mikroorganisme pada telapak tangan [7].

Jeruk nipis merupakan tanaman terapeutik keluarga yang dimanfaatkan secara umum, baik untuk penyedap masakan maupun untuk pengobatan [8]. Sebagai pengobatan, jeruk nipis umumnya digunakan untuk meningkatkan nafsu makan, menurunkan demam, menjaga kebugaran tubuh, mengatasi perut kembung, meredakan dan obat antibakteri. Masalah yang dihadapi dalam pemanfaatan buah jeruk adalah pengolahan bagian lain dari buah jeruk seperti kulit dan daun yang belum optimal. Salah satu jenis limbah hortikultura yang belum dimanfaatkan secara optimal adalah bagian kulit buah jeruk. Kulit buah jeruk nipis sering kali dibuang begitu saja pada pemanfaatan jeruk nipis sebagai jus, obat, makanan atau pemanfaatan lainnya. Kulit buah jeruk nipis merupakan bahan yang tidak terpakai yang dapat diproses untuk menghasilkan suatu produk berkualitas yaitu ekstrak yang mengandung minyak atsiri dan beberapa komponen kimia yang banyak manfaatnya untuk kehidupan manusia [9].

Berdasarkan latar belakang yang digambarkan di atas, tinjauan diarahkan untuk menentukan daya antiseptik dengan pengembangan tanaman lidah buaya dan jeruk nipis. Gabungan antiseptik antara lidah buaya dan tanaman jeruk nipis yang dipercaya memiliki khasiat dan hasil sesuai persyaratan pembersih antiseptik yang dapat membunuh jamur Candida albicans. Penelitian ini diharapkan dapat memutuskan apakah antiseptik yang mengandung lidah buaya dan jeruk nipis memiliki daya bunuh kuman sebagai daya bunuh terhadap pertumbuhan Candida albicans.

\section{Material dan Metode}

\section{Bahan dan Alat}

Bahan pada penelitian ini yang digunakan yaitu media Nutrient Agar (NA), natrium hidroksida, Buffer Fosfat, natrium klorida, aquades, alkohol, lidah buaya, jeruk nipis dan biakan jamur Candida albicans.

Alat pada penelitian yang digunakan yaitu, autoclave, oven, colony counter, vortex, mikro pipet, spatula, erlenmeyer, gelas ukur, neraca analitik, cawan petri, laminar air flow, ose bulat, tabung reaksi, bunsen, beaker glass, pipet ukur, pipet pump, incubator, alumunium foil.

\section{Metode}

Metode dalam penelitian ini adalah uji coba yang merupakan pemeriksaan yang dilakukan yang ditujukan untuk mengetahui pengaruh pelaksanaan suatu objek eksplorasi yang diamati [10]. Dalam ulasan ini, peneliti menggunakan eksplorasi percobaan untuk memutuskan kekuatan daya bunuh jamur terhadap organisme Candida albicans. Teknik pengujian dalam penelitian ini menggunakan strategi percentage kill dengan dua kali kontak pengujian yaitu 30 dan 60 detik. Dalam tinjauan ini, variabel bebasnya adalah sediaan antiseptik dengan formula ekstrak jeruk nipis dan lidah buaya. Variabel dependen dalam penelitian ini adalah kekuatan membunuh total terhadap jamur Candida albicans.

Tabel 1. Formula sediaan antiseptik dengan ekstrak jeruk nipis dan lidah buaya

\begin{tabular}{|c|c|}
\hline \multicolumn{2}{|c|}{ Formula } \\
\hline Bahan & mL \\
\hline Alkohol & 833,3 \\
\hline Ekstrak Lidah Buaya & 14,5 \\
\hline Ekstrak Jeruk Nipis & 41,7 \\
\hline Aquadest ad & 1000 \\
\hline
\end{tabular}


e-Jurnal Ilmiah BIOSAINTROPIS (BIOSCIENCE-TROPIC)

Volume 7/ No.: 2 / Halaman 126 - 132 / Januari Tahun 2022

ISSN : 2460-9455 (e) - 2338-2805(p)

\section{Ekstraksi Jeruk Nipis dan Lidah Buaya}

Pembuatan ekstrak jeruk nipis didapat dengan cara jeruk nipis dipilih yang sudah matang dengan warna hijau dan bau yang khas. Jeruk tersebut dicuci dengan air agar bersih. Keseluruhan jeruk nipis dikupas menjadi, jeruk nipis tersebut diperas dan disaring dengan saringan.

Pembuatan ekstrak tanaman lidah buaya didapat dengan mengambil tanaman lidah buaya yang dicuci terlebih dahulu dan dihilangkan durinya sampai bersih, kemudian dipotong dan dipisahkan antara kulit dan daging tanaman lidah buaya. Setelah itu diambil daging lidah buaya, dipotong kecil, dilanjutkan dengan menghaluskan dengan blender, disaring hingga diperoleh filtrate berupa ekstrak lidah buaya.

\section{Cara Pembuatan}

Pembuatan antiseptik dengan ekstrak jeruk nipis dan lidah buaya: dimasukkan etanol ke gelas ukur sesuai takaran sesuai formula, setelah itu dituangkan ke dalam beaker gelas 1 Liter, Takar ekstrak lidah buaya dan jeruk nipis yang telah dibuat sesuai formula ke dalam gelas ukur sesuai takaran pada gelas ukur terpisah, dimasukan ekstrak lidah buaya dan ekstrak jeruk nipis kedalam beaker yang sudah berisi etanol yang telah ditakar sesuai formula, Kemudian ditambahkan aquadest aduk hingga homogen sampai terbentuk sediaan antiseptik sempurna. Campuran dituangkan dalam botol rapat agar tidak mudah menguap.

\section{Pengujian \\ Pengukuran pH}

$\mathrm{pH}$ meter disesuaikan dengan pengaturan pendukung seperti yang ditunjukkan oleh arah kerja peralatan setiap kali mengambil estimasi pengukuran. Keringkan dan bersihkan alat $\mathrm{pH}$ meter kemudian siram elektroda dengan air. Cuci elektroda dengan sampel yang akan dilakukan tes. dicelupkan elektroda ke dalam tes sampel sampai $\mathrm{pH}$ meter menunjukkan pembacaan yang konsisten. Catat pembacaan skala atau angka pada penyajian $\mathrm{pH}$ meter.

\section{Penetapan Bobot Jenis}

Bobot jenis diatur dengan menggunakan piknometer. Piknometer pada pengujian bobot jenis harus dibersihkan dan dikeringkan terlebih dahulu. Pada suhu kamar, piknometer kosong diukur. Kemudian pada saat itu piknometer diisi dengan air sampai penuh dan ditimbang kembali. Air dikeluarkan dari piknometer dan dikeringkan. Kemudian sampel yang diuji tersebut dimasukkan ke dalam piknometer sampai penuh dan diukur. Lalu dilakukan perhitungan dan ditetapkan bobot jenis sampel.

\section{Uji Percentage Kill}

Uji Percentage kill merupakan suatu strategi untuk menentukan efektivitas anti jamur dengan menggunakan metode plate count dan pemeriksaan persen dan penurunan log. Setelah menyiapkan kultur parasit, tempatkan sejumlah tes uji yang memadai untuk menguji ke dalam cawan petri steril. Kemudian sejumlah kultur jamur spike $1 \mathrm{~mL}(107 \mathrm{CFU} / \mathrm{mL})$ ke dalam sampel yang akan diuji, di inokulasi kedalam cawan petri sebelumnya dan kemudian segera diaduk. Setelah waktu kontak yang telah ditentukan, sejumlah kecil dari campuran jamur dan sampel uji diambil, dan dimasukkan ke dalam cawan berisi agar nutrisi dan kemudian diinkubasi dan hitung menggunakan rumus untuk menghitung reduksi log. 
e-Jurnal Ilmiah BIOSAINTROPIS (BIOSCIENCE-TROPIC)

Volume 7/ No.: 2 / Halaman 126 - 132 / Januari Tahun 2022

ISSN : 2460-9455 (e) - 2338-2805(p)

\section{Hasil dan Diskusi}

Hasil pemeriksaan yang telah dilakukan pada antiseptik terhadap Candida albicans menggunakan teknik Percentage kill dengan dua waktu kontak yaitu 30 dan 60 detik. Sediaan antiseptik dari pengujian organoleptik diperoleh dalam struktur cairan dengan aroma jeruk nipis yang khas dan memiliki warna putih transparan. Hasil yang didapat untuk berat jenis sediaan antiseptik yang mengandung jeruk nipis dan ekstrak lidah buaya adalah $0,9736 \mathrm{~g} / \mathrm{ml}$. Bobot jenis suatu bahan atau zat adalah proporsi berat bahan atau zat terhadap air/cairan dalam volume dan ditimbang pada suhu kamar yang sesuai. Mengingat kontrol yang diperoleh sesuai referensi bahwa bobot jenis dari pengujian adalah $0,9411 \mathrm{~g} / \mathrm{ml}$.

Pengujian $\mathrm{pH}$ adalah dengan memperkirakan aksi partikel hidrogen melalui atau potensiometri/elektrometri menggunakan $\mathrm{pH}$ meter. $\mathrm{pH}$ adalah derajat atau dapat dianggap sebagai derajat keasaman yang digunakan untuk menyampaikan tingkat atau alkalinitas suatu larutan. Skala pH sama sekali bukan skala langsung atau jelas. Ini mirip dengan pengaturan standar $\mathrm{pH}$ yang dibatasi oleh pertunjukan global. Penilaian $\mathrm{pH}$ diperlukan dalam bidang yang dibedakan melalui kehidupan atau bisnis yang berurusan dengan campuran seperti sains, pengobatan, budidaya, sains kesehatan, rencana modernisasi dan oseanografi. Jelas berbagai bidang ilmu pengetahuan dan kemajuan juga menggunakannya namun pada tingkat yang lebih rendah. Dapat diungkapkan dengan sangat baik bahwa untuk mengukur $\mathrm{pH}$ ada beberapa cara jawaban dapat digunakan, jelas seseorang dapat menggunakan kertas lakmus, kertas penunjuk atau kertas indikator dan menggunakan $\mathrm{pH}$ meter. Pada penilaian $\mathrm{pH}$, sediaan antiseptik dalam tinjauan memiliki $\mathrm{pH}$ senilai 5 yang masih dianggap asam karena zat asam alami dari jeruk nipis yang diketahui memiliki $\mathrm{pH}$ asam, membuat sediaan antiseptik memiliki karakteristik $\mathrm{pH}$ asam dari elemen jeruk nipis yang merupakan bahan alam.

Pengujian sediaan antiseptik dilakukan untuk memutuskan pengaruh desinfektan pada daya bunuh jamur dari antiseptik yang telah dibuat terhadap Candida albicans dan daya bunuh jamur yang dicoba khususnya pada waktu kontak 30 detik dan 60 detik. Seperti yang ditunjukkan oleh oleh United states Food and Drugs Administration (US FDA) pembersih tangan antiseptik dapat dengan cepat mengurangi jumlah jamur dalam 30 detik hingga 60 detik. Selain pembasmi jamur, berapa organisme juga banyak di tangan berubah jumlahnya, bergantung pada beberapa faktor, terutama waktu sejak terakhir kali membersihkan yang akan mempengaruhi lingkungan parasit di tangan. Komponen berikut adalah tingkat noda sesuai kontak. Hal ini menunjukkan bahwa semakin tinggi derajat kotoran, semakin terlihat jumlah mikroorganisme. Faktor ketiga adalah tingkat kelemahan individu terhadap mikroorganisme. Semakin tinggi tingkat kelemahan individu terhadap mikroorganisme, maka semakin lengkap dan semakin luas kuantitas mikroorganisme yang ada [11].

Uji coba daya bunuh untuk jamur pada antiseptik dengan jeruk nipis dan lidah buaya terhadap Candida albicans diperoleh dengan memanfaatkan teknik Percentage kill dan Candida albicans yang dapat dihilangkan dengan cara sediaan antiseptik, yang memiliki Percentage kill senilai 99,9\% untuk waktu kontak 30 dan 60 detik. Dalam analisis ini, diklarifikasi bahwa konsekuensi kualitas antiseptik dengan jeruk nipis dan lidah buaya memiliki kualitas yang sangat baik, mengingat efek dari uji daya bunuh kuman yang tinggi, baik untuk setiap waktu kontak atau dengan hasil di atas $90 \%$. Antiseptik dengan jeruk nipis dan lidah buaya yang dicoba adalah cairan yang mengandung alkohol yang dimaksudkan untuk aplikasi ke tangan untuk mengurangi jumlah mikroorganisme patogen. Alkohol adalah bagian anti bakteri yang digunakan di sebagian besar pembasmi kuman. Antiseptik berbasis alkohol sangat kuat terhadap berbagai jenis organisme mikroskopis, khususnya gram positif dan gram negatif, seperti halnya jamur. Antiseptik dapat mengatasi halangan terhadap kebersihan dan meningkatkan kepatuhan karena mereka membutuhkan lebih sedikit waktu ideal untuk mencuci tangan dengan baik, tidak terlalu berbahaya bagi kulit dari pembersih tangan seperti sabun dan air lebih kuat 
e-Jurnal Ilmiah BIOSAINTROPIS (BIOSCIENCE-TROPIC)

Volume 7/ No.: 2 / Halaman 126 - 132 / Januari Tahun 2022

ISSN : 2460-9455 (e) - 2338-2805(p)

dalam membunuh banyak mikroorganisme. Dalam pengertian pembuatan antiseptik, alkohol yang digunakan adalah etanol, isopropanol atau n-propanol, atau campuran keduanya.

\section{Kesimpulan}

Dilihat dari hasil penelitian yang telah selesai, ditemukan bahwa antiseptik membersihkan dengan membunuh jamur Candida albicans dengan mengurangi jumlah koloni berdasarkan bahan aktif yang terkandung. Tingkat daya bunuh terhadap jamur Candida albicans oleh antiseptik yang dibuat dengan tingkat daya membunuh jamur Candida albicans 99,9\%. Pemeriksaan lebih lanjut tentang daya bunuh jamur Candida albicans dengan bahan pembersih dengan konsentrat bahan lainnya seperti terhadap berbagai pertumbuhan selain Candida albicans sehingga kualitas dan viabilitas antiseptik dapat lebih diketahui.

\section{Ucapan Terima Kasih}

Puji syukur dan terima kasih diucapkan sebesar-besarnya kepada Allah SWT atas segala rahmat, hidayah dan segala nikmat yang telah diberikan. Dalam penyusunan ini tidak terlepas dukungan dari berbagai pihak. Peneliti secara khusus mengucapkan terima kasih yang sebesar-besarnya kepada semua pihak yang telah membantu. Peneliti banyak menerima bimbingan, petunjuk dan bantuan serta dorongan dari berbagai pihak baik yang bersifat moral maupun material.

\section{Daftar Pustaka}

[1] D. Silvia, "Uji Aktivitas Antifungi Ekstrak Kulit Buah Jeruk Nipis (Citrus aurantifolia) Terhadap Jamur Candida albicans.," Skripsi, pp. 57-84, 2018.

[2] S. Indrayati and R. I. Sari, "Gambaran Candida albicans Pada Bak Penampung Air Di Toilet Sdn 17 Batu Banyak Kabupaten Solok," J. Kesehat. PERINTIS (Perintis's Heal. Journal), vol. 5, no. 2, pp. 133-138, 2018, doi: 10.33653/jkp.v5i2.148.

[3] A. Asmawati and M. A. Setiawan, "Perbandingan Daya Hambat Antiseptik Kewanitaan Herbal Dan Non Herbal Terhadap Jamur Candida albicans," War. Farm., vol. 6, no. 1, pp. 82-89, 2017.

[4] R. Sari and D. Isadiartuti, "Studi efektivitas sediaan gel antiseptik tangan," Maj. Farm. Indones., vol. 17, no. 4, pp. 163-169, 2006, [Online]. Available: http://ilib.ugm.ac.id/jurnal/detail.php?dataId=10171.

[5] T. Y. Hendrawati, R. A. Nugrahani, and H. Gustia, "Pembagian Hand Sanitizer Kepada Masyarakat Terdampak Covid 19 Sekitar Kampus Umj," vol. 3, pp. 71-76, 2021, doi: 10.24853/jpmt.3.2.71-76.

[6] S. N. Rismawati and I. Ismiyati, "Pengaruh Variasi Ph Terhadap Kadar Flavonoid Pada Ekstraksi Propolis Dan Karakteristiknya Sebagai Antimikroba," J. Konversi, vol. 6, no. 2, p. 89, 2017, doi: 10.24853/konversi.6.2.89-94.

[7] D. W. Dewi, S. Khotimah, and D. F. Liana, "Pemanfaatan Infusa Lidah Buaya (Aloe vera L) sebagai Antiseptik Pembersih Tangan terhadap Jumlah Koloni Kuman," J. Cerebellum, vol. 2, pp. 577-589, 2013. 
e-Jurnal Ilmiah BIOSAINTROPIS (BIOSCIENCE-TROPIC)

Volume 7/ No.: 2 / Halaman 126 - 132 / Januari Tahun 2022

ISSN : 2460-9455 (e) - 2338-2805(p)

[8] A. Razak, A. Djamal, and G. Revilla, "Uji Daya Hambat Air Perasan Buah Jeruk Nipis (Citrus aurantifolia s.) Terhadap Pertumbuhan Bakteri Staphylococcus Aureus Secara In Vitro," J. Kesehat. Andalas, vol. 2, no. 1, p. 05, 2013, doi: 10.25077/jka.v2i1.54.

[9] N. Istikomah, "Pengaruh Ekstrak Kulit Jeruk Pamelo Terhadap Pertumbuhan Tanaman Tomat Yang Terinfeksi Jamur Penyakit Layu Fusarium oxysporum,” pp. 1-4, 2015.

[10] D. Sawitri, "Pengaruh Pelatihan Berpikir Positif Pada Efikasi Diri Akademik Mahasiswa (Studi Eksperimen Pada Mahasiswa Fakultas Psikologi Undip Semarang," Pengaruh Pelatih. Berpikir Positif Pada Efikasi Diri Akad. Mhs. (Studi Eksperimen Pada Mhs. Fak. Psikol. Undip Semarang, vol. 8, no. 2, pp. 135-144, 2010, doi: 10.14710/jpu.8.2.135-144.

[11] Kementerian Kesehatan Republik Indonesia, Pedoman Manajerial Infeksi di Rumah Fasilitas Pelayanan Kesehatan Lainnya. 2017. 